\title{
Tenk på et tall!
}

I kjølvannet av Hjernevask-programmene på NRK ble samfunnsforskere kritisert for ikke å benytte seg mer av registerdata. Det ble fortolket for mye og telt for lite (1). Kombinasjonen av en stabil befolkning og datateknologi har gjort norske databaser til et eldorado for registerforskning. Men resultatene av tellingen er avhengig av at grunndata er korrekt. Utsagnet «søppel inn gir søppel ut» mister ikke sin gyldighet ved at databasen blir tilgjengelig på nett. Sentralt i helseforskningen står Norsk pasientregister, et register der det ikke telles, men fortolkes. Data er basert på at legene tolker sykdomsforløpet objektivt og klarer å oversette dette til koder. Arbeidet med koding er krevende, og det er ikke gitt at alle har like stort fokus på helseforskning når kodene velges. Kodingen skjøt da også først fart da den ble koplet mot innsatsstyrt finansiering (ISF). Dette betyr ikke nødvendigvis at leger lar seg påvirke av sykehusøkonomi og kreative kodekonsulenter og koder ut fra lønnsomhet. Men sett utenfra gjør det faktum at valg av ICDkoder er medvirkende til sykehusenes økonomi, at Pasientregisteret må anses som et lærebokeksempel i mulig skjevfordelte data.

Samsvaret mellom ICD-koder og det faktiske journalinnholdet er dels avhengig av type sykdom. Kunnskapssenteret fant overensstemmelse i $95 \%$ av kodingen ved relativt enkle sykdomsforløp som hjerneslag, hjerteinfarkt og hoftefrakturer (2), mens rapporter fra SINTEF har vist sprik mellom koding og journalinnhold i opp mot $40 \%$ (3, 4). Størst var avvikene ved medisinske akuttinnleggelser og ved registrering av bidiagnoser. Rapporten fra 2003 påpeker at dårlig kodepraksis er spesielt alarmerende i forskningsøyemed, fordi man ikke vet om avvikene skyldes systematisk vridning, for eksempel av hensyn til økonomi, eller om feilene er tilfeldige. Sju år senere har man fortsatt ikke noe svar på dette.

Muan og medarbeidere bekrefter i dette nummer av Tidsskriftet at kodingen av akuttinnleggelser er mangelfull (5). En gjennomgang av 235 sykehistorier ved forgiftningsdødsfall viste at $20 \%$ ikke var forgiftninger i det hele tatt. Av de gjenværende var $46 \%$ kodet feil, med forgiftning som bidiagnose. Med slike feilmarginer synes forfatternes konklusjon om at kodingen virker tilfeldig, som et «understatement». Forfatterne trøster oss med at Dødsårsaksregisteret vil kunne justere feil gjennom tolking av dødsattestene og at dødsårsaksstatistikken derfor ikke nødvendigvis er like upresis som de koder som går videre til Pasientregisteret. En korreksjon av dødsårsaken ved Dødsårsaksregisteret vil imidlertid være avhengig av at dødsattestene gjenspeiler det virkelige forløpet, og at forgiftning i det hele tatt er nevnt. Dessverre er ikke dette alltid tilfellet (6). Når korrigering av dødsattestene gjennom obduksjon også mangler, kan data ikke bli annet enn misvisende.

Forgiftningsdødsfallene i Muan og kollegers arbeid ble bare unntaksvis bekreftet av obduksjon eller toksikologiske analyser. Her kan det skjule seg selvmord. Fallende selvmordsrater de siste årene har vært tilskrevet effekten av nye antidepressiver (7), men hvor sikre er disse data? Kurvene for antall selvmord og rettsmedisinske undersøkelser er påfallende parallelle (fig 1). Det er derfor nærliggende å anta at manglende melding og oppfølging av unaturlig død gjør at mange forgiftningsselvmord ikke lenger oppdages eller registreres. Sammenlikner man summen av selvmord med gift og akutte forgiftningsdødsfall for 1996 og 2008, finner man da heller ingen nedgang, men en økning på $29 \%$. Uten bedre kvalitetssikring av registertallene, kan vi altså ikke si at selvmordsratene faller. Med

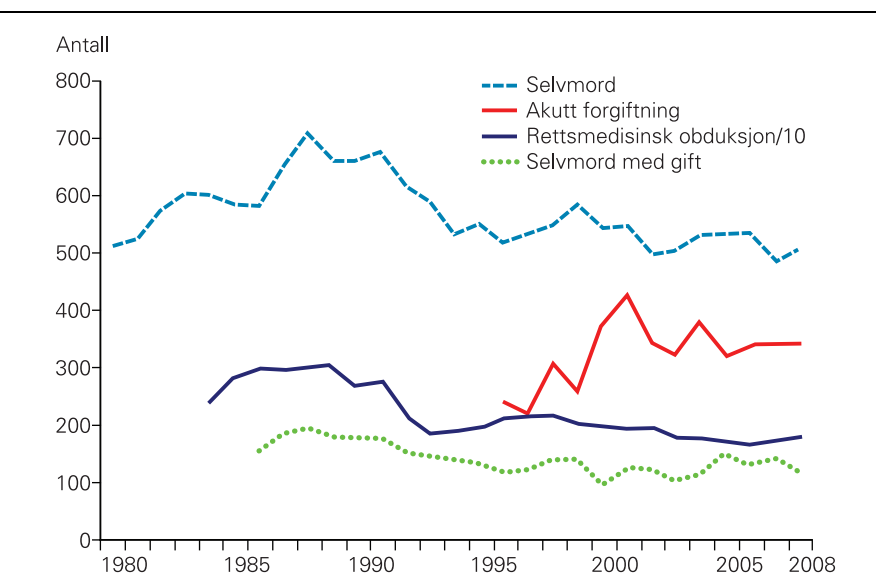

Figur 1 Selvmord, akutte forgiftninger og rettsmedisinske undersøkelser 1980-2008. Tall fra Statistisk sentralbyrå og Den norske patologforening. Rettsmedisinske undersøkelser er vist som tidel av originaltallene

basis i offentlige registre kan man like gjerne hevde at økt salg av nye antidepressiver gir økende selvmordsrater!

Det er ikke første gang at man i Tidsskriftet påpeker dårlig kodepraksis (8). Modulbaserte sykejournaler vil kunne forenkle oversettelse til koder, men ligger mange år frem i tid. I mellomtiden er man nødt til å bryte koplingen av ICD-koder mot sykehusøkonomi og finne andre måter å belønne kodearbeidet på. Øremerkede midler og stillinger, uavhengig av kodevekting og DRG, må på plass! Overvåking av endringer i sykdomsmønstre eller medikamentbivirkninger krever populasjoner på flere millioner og derfor overnasjonalt samarbeid (9). Med etablerte registre og en samlet populasjon på 25 millioner kan de nordiske landene samarbeide effektivt. Men skal Norge kunne bidra, må kvalitetssikringen av helseregistrene tas på alvor. Å kaste mynt og krone er neppe et egnet beslutningsgrunnlag i et moderne helsevesen.

\section{G. Cecilie Alfsen}

cecilie.alfsen@medisin.uio.no

G. Cecilie Alfsen er spesialist i patologi, overlege ved Laboratoriesenteret, Akers hus universitetssykehus, og førsteamanuensis ved Det medisinske fakultet, Universitetet $i$ Oslo.

\section{Litteratur}

1. Forskningsrådet. www.forskningsradet.no/no/Nyheter/_Teller_lite_fortolker mye/1253954822670 (15.5.2010).

2. Methodological development and evaluation of 30 -day mortality as quality indicator for Norwegian hospitals. Rapport nr. 4/2005. Oslo: Kunnskapssenteret, 2005.

3. Midttun L, Sverrbo E, Thorsen G et al. Er det sammenfall mellom journalopplysninger og innrapporterte data? STF78A035504. Trondheim: SINTEF Unimed, 2003.

4. Jørgenvåg R, Hope ØB. Kvalitet på medisinsk koding og ISF-refusjoner. STF78A055501. Trondheim: SINTEF Helse, 2005.

5. Muan $B$, Heyerdahl F, Lindås $R$ et al. Kodepraksis ved forgiftningsdødsfall. Tidsskr Nor Legeforen 2010; 130: 1601-5.

6. Alfsen GC, Lyckander LG, Lindboe AW et al. Kvalitetssikring ved dødsfall i sykehus. Tidsskr Nor Legeforen 2010; 130: 476-9.

7. Bramness JG, Walby FA, Tverdal A. The sales of antidepressants and suicide rates in Norway and its counties 1980-2004. J Affect Disord 2007; 102: 1-9.

8. Rygnestad T. Akutte forgiftninger og statistikk. Tiddskr Nor Lægeforen 2007; 127: 1022

9. Skegg DC, Doll R. Record linkage for drug monitoring. J Epidemiol Community Health 1981; 35: 25-31 